\title{
Los permisos retribuidos tras un periodo de turbulencias judiciales
}

\author{
Paid time off after a period \\ of judicial turbulence
}

\author{
Nora María Martínez Yáñez \\ Profesora Contratada Doctora (TU acreditada) de Derecho del Trabajo y de la Seguridad Social \\ Universidad de Vigo
}

ORCID ID: 0000-0001-7370-7080

Researcher ID: L-3465-2014

Recibido: 04/06/2020

Aceptado: 03/10/2020

doi: https://doi.org/10.20318/labos.2020.5775

Resumen: La primera mitad del año 2020 ha sido especialmente prolífica en pronunciamientos del Tribunal Supremo en torno a los permisos retribuidos. Incluso el Tribunal de Justicia de la Unión Europea ha tenido ocasión de pronunciarse sobre una cuestión prejudicial planteada por la Audiencia Nacional en relación con esta institución. La mayor parte de estas resoluciones traen causa de un debate abierto entre la Audiencia Nacional y el Tribunal Supremo en torno a la forma de cómputo de los permisos retribuidos. La contundencia y reiteración del criterio del Tribunal Supremo en varias sentencias dictadas en marzo justifica la necesidad de analizar las líneas jurisprudenciales que han emergido del debate, destacando además otros avances jurisprudenciales en materia de retribución de los permisos.

Palabras clave: permisos retribuidos, dies a quo, cómputo, retribución.

Abstract: $\quad$ The first half of 2020 has been especially prolific in Supreme Court rulings on paid leave. Even the Court of Justice of the European Union has had the opportunity to rule on a preliminary ruling raised by the National Court in relation to this institution. Most of these resolutions have their origin in a debate between the National Court and the Supreme Court regarding the way of calculating the paid leave. The firmness and reiteration of the criterion of the Supreme Court in several judgments issued in March justifies the need to analyze the jurisprudential lines that have emerged from the debate, also highlighting other jurisprudential advances in the matter of remuneration.

Keywords: $\quad$ paid leave, dies a quo, computation, compensation. 


\section{Introducción}

Las instituciones que atienden las distintas vicisitudes que impiden temporalmente la ejecución de la prestación laboral tienen una relevancia especial en el contrato de trabajo, dada su configuración como un contrato de tracto sucesivo que puede alcanzar una duración prolongada. De conformidad con el principio de estabilidad en el empleo, la finalidad general de dichas instituciones consiste en preservar el vínculo laboral y atribuir a la persona trabajadora derechos que le permitan volver a prestar servicios en su puesto de trabajo o en otro similar cuando cesen las circunstancias impeditivas.

Aunque la legislación admite que algunas causas relacionadas con la situación de la empresa puedan provocar la suspensión de la relación laboral -por ejemplo, las causas económicas, técnicas, organizativas, productivas o de fuerza mayor-, hay un amplio abanico de circunstancias capaces de interrumpir la relación laboral que provienen de la persona trabajadora y por regla general se refieren a situaciones personales o familiares, o bien al cumplimiento de deberes públicos o sindicales, cuya atención resulta incompatible con la ejecución de la prestación de servicios.

Junto con las suspensiones o las excedencias, los permisos retribuidos son una de las instituciones que el ordenamiento jurídico dispone para atender a los fines expuestos ${ }^{1}$. Pero, a diferencia de aquellas, las situaciones que contemplan los permisos retribuidos son de carácter puntual y transitorio, algunas incluso sobrevenidas e imprevisibles, de modo que el cese de la relación laboral solo es preciso durante un breve periodo de tiempo².

En sentido estricto, la interrupción que comportan los permisos no es objetivamente inevitable, como por el contrario sucede en las suspensiones por incapacidad para trabajar derivada de enfermedad, accidente o parto; pero se trata de una exigencia ligada a relevantes derechos y principios del ordenamiento jurídico, como la conciliación de la vida laboral y familiar, la libertad sindical o la dignidad humana. Por ello se confiere a la persona trabajadora un derecho a hacer uso del permiso si se dan los presupuestos habilitantes, previo aviso al empresario y posterior justificación.

El artículo 37.3 ET expone las causas que pueden dar acceso a los permisos retribuidos y la duración correspondiente a cada uno de ellos ${ }^{3}$. Aunque este precepto contiene el régimen jurídico aplicable a los permisos, resulta bastante parco e inconcreto en muchos de sus aspectos. Así, se habla de retribución, pero no se indica cuál ha de ser esta; tampoco se especifica en la mayor parte de los permisos si los días son naturales, laborables o hábiles; no se precisa el plazo de preaviso ni el tipo de justificación, aunque son cuestiones de indudable trascendencia práctica cuyo incumplimiento puede dar lugar a sanciones, incluido el despido; ni se abordan aspectos problemáticos como el solapamiento con otros permisos o con periodos en los que no hay actividad laboral.

Esta falta de detalle es deliberada, pues el artículo 37.3 ET funciona como una garantía mínima que puede ser ampliada, mejorada y desarrollada por la negociación colectiva. La jurisprudencia ha reiterado que esta es una norma imperativa de derecho necesario relativo, según lo dispuesto en el

${ }^{1}$ Sobre la configuración general de los permisos retribuidos, véase SÁNCHEZ TRIGUEROS, C., Los permisos retribuidos del trabajador (Régimen jurídico de las interrupciones no periódicas, preavisadas y justificadas del contrato de trabajo), Aranzadi, Pamplona (1999) 25-71. También RODRÍGUEZ ESCANCIANO, S., Los permisos parentales: avances y retrocesos tras las últimas reformas, Bomarzo, Albacete (2013) 13.

${ }^{2}$ SSTS de 3 de diciembre de 2019, rec. 141/2018, de 11 de marzo de 2020, rec. 192/2018, f. j. $2^{\circ}$ y de 17 de marzo de 2020, rec. $193 / 2018$, f. j. $2^{\circ}$.

${ }^{3}$ En la actualidad las causas legales de los permisos retribuidos son el matrimonio -letra a)-; el fallecimiento, accidente o enfermedad graves, hospitalización o intervención quirúrgica sin hospitalización que precise reposo domiciliario, de parientes hasta el segundo grado de consanguinidad o afinidad -letra b)-; el traslado del domicilio habitual -letra c)-; el cumplimiento de un deber inexcusable de carácter público y personal, comprendido el ejercicio del sufragio activo -letra d)-; la realización de funciones sindicales o de representación del personal -letra e)-; y, por último, la realización de exámenes prenatales y técnicas de preparación al parto, o bien, en los casos de adopción, guarda con fines de adopción o acogimiento, la asistencia a las preceptivas sesiones de información y preparación y para la realización de los informes psicológicos y sociales previos a la declaración de idoneidad -letra f)-. 
artículo 3.3 ET, que "permite su mejora, pero no su empeoramiento -en ambos casos desde el punto de vista del trabajador- vía convenio colectivo o contrato individual de trabajo" ${ }^{4}$. Ciertamente, por su cercanía a las necesidades personales de los trabajadores y a la gestión empresarial de los tiempos de trabajo, los permisos conforman una materia especialmente idónea para ser desarrollada a través de convenios o acuerdos de naturaleza colectiva. En este sentido, las posibilidades de la negociación colectiva son amplias, y van desde la creación de nuevas causas generadoras del derecho al permiso, hasta la ampliación de los días de disfrute, bien de forma directa -fijando una cantidad mayor- o indirecta -indicando que se trata de días hábiles en vez de naturales-, entre otras alternativas.

No obstante, la articulación entre la ley y el convenio colectivo no siempre resulta sencilla y su interpretación en casos concretos se encuentra en la base de recientes pronunciamientos jurisprudenciales. Buen ejemplo de ello son las controversias motivadas por la desaparición del permiso de dos días por nacimiento de hijo en la nueva redacción del artículo 37.3.b) ET, dada por el Real Decreto-ley 6/2019, de 1 de marzo, de medidas urgentes para garantía de la igualdad de trato y de oportunidades entre mujeres y hombres en el empleo y la ocupación. Puesto que muchas disposiciones convencionales todavía recogen el tenor literal del precepto anterior a la reforma e incluso mejoran la duración del citado permiso, cabe preguntarse si deben seguir operando una vez que se produce su desaparición en el plano legal. A este respecto, resulta acertado el criterio de la Audiencia Nacional, que considera que la derogación del permiso legal no afecta a la supervivencia de la norma convencional que lo reproducía, pues lo único que desaparece es el mínimo de Derecho necesario que obligaba a conceder este tipo de permiso, hubiera sido recogido en el convenio o no 5 . Por tanto, mientras las partes legitimadas no modifiquen o eliminen la disposición convencional que enuncia el permiso por nacimiento, este seguirá siendo aplicable ${ }^{6}$. Cosa distinta sucedería si el convenio, en vez de reproducir el tenor literal del artículo 37.3.b) ET, se hubiese limitado a hacer una simple remisión al mismo, pues en este supuesto, la desaparición legal del permiso por nacimiento repercutiría también en el ámbito del convenio colectivo.

En definitiva, a pesar de la aparente simplicidad de esta institución, que cuenta con una amplia tradición en el ordenamiento jurídico, en los últimos años se han sucedido pronunciamientos de diversos órganos judiciales que han abordado de manera novedosa estos y otros aspectos relevantes, como el derecho a la remuneración durante el disfrute de los permisos o el cómputo de los días de permiso y, en particular, la determinación del dies a quo.

Esa agitación del panorama judicial justifica la pertinencia del presente análisis. Tras varias sentencias dictadas en los primeros meses del presente año que zanjan la polémica abierta entre la Audiencia Nacional y el Tribunal Supremo y arrojan luz sobre la posición de este último, es hora de revisar la jurisprudencia sobre los permisos, en especial la que se refiere a su cómputo, a fin de comprobar si verdaderamente ha habido tantos cambios como parece, o si, por el contrario, las novedades son más aparentes que reales. En este sentido, hay que destacar que uno de los factores que pueden obstaculizar una clara apreciación de la doctrina jurisprudencial es el intenso casuismo presente en esta materia, que no solo obliga al Tribunal Supremo a interpretar la institución a través de su plasmación en las cláusulas de diversos convenios colectivos, sino que además modula el razonamiento jurídico en función del tipo de permiso que se esté abordando.

Por otro lado, la solución a las cuestiones planteadas en relación con el cómputo de los permisos exige una cabal comprensión de un elemento nuclear en esta institución, como es la causa

\footnotetext{
${ }^{4}$ Por todas, SSTS de 25 de enero de 2011, rec. 216/2009, f. j. $4^{\text {o }}$ y 5o; de 5 de marzo de 2012, rec. 57/2011, f. j. $3^{\text {o; }}$ de 13 de febrero de 2018, rec. 266/2016, f. j. $2^{\circ}$.

${ }^{5}$ SAN de 29 de noviembre de 2019 , rec. $221 / 2019$, f. j. $4^{\circ}$.

${ }^{6}$ Sin embargo, no todos los órganos judiciales sostienen este parecer, como evidencia la STSJ del País Vasco de 16 de julio de 2019, rec. 16/2019, para la cual "no puede aceptarse la vigencia en el convenio de la mejora de un derecho legal que ya no existe".
} 
que motiva la interrupción de la relación laboral, toda vez que el disfrute del permiso debe servir a su satisfacción.

En consecuencia, el presente estudio se estructura en tres partes. En primer lugar, un análisis del derecho a la remuneración en el disfrute de los permisos que pretende examinar pronunciamientos recientes de especial interés sobre esta materia. En segundo lugar, un examen de los elementos esenciales de los permisos retribuidos, que son la exigencia de causalidad y la exoneración del deber de trabajar. Y, en tercer lugar, el estudio de las líneas jurisprudenciales que emergen de diversas sentencias del Tribunal Supremo y del Tribunal de Justicia de la Unión Europea dictadas en 2020 acerca del cómputo de los días de permiso y del solapamiento entre estos y otros días de descanso, respectivamente. El previo análisis de los elementos esenciales de la institución permitirá comprender cómo y por qué el Tribunal Supremo alcanza sus conclusiones y sienta doctrina.

\section{Algunas notas sobre el carácter retribuido de los permisos}

Uno de los aspectos distintivos de la interrupción de la actividad laboral provocada por el uso de los permisos es el mantenimiento del derecho a la retribución. Probablemente la breve duración de la mayoría de los permisos y el hecho de que se trate de situaciones puntuales justifica que la ley atribuya su coste al empresario, propiciando una ruptura del carácter sinalagmático del contrato de trabajo que pone de manifiesto la finalidad tuitiva del Derecho del Trabajo, todavía muy presente en esta institución.

Pese a todo, la referencia del artículo 37.3 ET al "derecho a remuneración" ha planteado numerosas dudas relativas a la inclusión o no en el citado derecho de la percepción de complementos salariales ligados al tiempo de trabajo o a la ejecución efectiva de la prestación laboral, como los complementos de productividad, jornada partida, nocturnidad, horas extras, disponibilidad horaria, transporte o primas de asistencia, entre otros. Las dificultades para dictar jurisprudencia sobre una cuestión extremadamente casuística y por tanto poco proclive a cumplir los requisitos del recurso de casación para la unificación de doctrina han alentado una amplia y variada doctrina judicial al respecto ${ }^{7}$.

Hasta hace poco tiempo la única pauta dada por el Tribunal Supremo se recogía en una sentencia de 1992 que, ante la parquedad del artículo 37.3 ET, afirmaba de forma igualmente escueta que la sola invocación del derecho a remuneración "conduce a sostener que deben incluirse el salario base y los complementos salariales que suman el salario real". Como consecuencia de ello, en el caso enjuiciado el tribunal fallaba que debía formar parte del salario percibido durante los días de permiso el plus de montaña, mediante el que se compensaban las circunstancias climatológicas y de aislamiento que afectaban a algunos centros de trabajo ${ }^{8}$. Sin embargo, poco después el Alto Tribunal mantenía una vieja doctrina del Tribunal Central de Trabajo a tenor de la cual el complemento salarial de trabajos nocturnos no se abonaba durante los permisos y licencias retribuidos?.

En la sentencia de 3 de diciembre de 2019, el Tribunal ha tenido la oportunidad de desarrollar de manera más fundada su doctrina sobre el derecho a remuneración correspondiente a los días de permiso, partiendo de que las alternativas posibles son dos: o bien se sostiene que debe mantenerse exactamente la misma retribución que hubiere percibido el trabajador de haber prestado servicios en los días de permiso, incluyendo la totalidad de complementos que percibe de ordinario; o bien

\footnotetext{
${ }^{7}$ Como ejemplo del difícil acceso de este tipo de litigios a la casación en unificación de doctrina, véase la STS de 12 de abril de 2012, rcud. 3077/2011 y el auto TS de 28 de enero de 2020, rcud. 1671/2019.

${ }^{8}$ STS de 20 de mayo de 1992, rec. 1634/1991, f. j. $4^{\circ}$.

${ }^{9}$ SSTS de 15 de septiembre de 1995, rec. 1997/1994, f. j. $3^{\circ}$ y de 18 de marzo de 2009, rcud. 98/2007, f. j. $3^{\circ}$.
} 
se admite que la propia negociación colectiva que ha creado tales complementos salariales pueda modular y limitar los conceptos retributivos a percibir en los días de permiso.

A juicio del Tribunal, el tenor literal del artículo 37.3 ET no permite deducir con certeza que el derecho a remuneración engloba la totalidad de las percepciones del trabajador, afirmación que parece apartarse de la vieja tesis en favor del "salario real". Por consiguiente, la clave para determinar el alcance y contenido de la remuneración durante los permisos ha de ser el artículo 26 ET, que deja en manos de la negociación colectiva la estructura salarial. En otras palabras, a falta de regulación legal al respecto, serán los términos del convenio colectivo los que determinen libremente el cálculo de la remuneración que corresponde a los días de permiso. Ahora bien, el tribunal no aclara qué solución ha de aplicarse cuando el convenio colectivo no especifique esta cuestión, lo que probablemente suceda con cierta frecuencia. Puesto que el Tribunal ha aseverado que de la literalidad del precepto no se desprende que el trabajador tenga derecho a la totalidad de las percepciones salariales, el silencio del convenio puede conducir a la exclusión de los complementos que se generan con la efectiva prestación de servicios o la productividad, como sucedía justamente en el supuesto examinado ${ }^{10}$.

En todo caso, la sentencia de 3 de diciembre de 2019 se centra en otro aspecto no menos interesante, como es la interpretación del derecho a remuneración de los permisos desde el punto de vista del principio de igualdad y no discriminación por razón de sexo.

A este respecto, el Tribunal recuerda que, aunque la negociación colectiva goce de libertad para excluir determinados complementos salariales de la remuneración durante los permisos, dicha facultad no es ilimitada, pues no puede contravenir principios esenciales del ordenamiento, como el de igualdad de mujeres y hombres. Por esa razón, la sentencia analiza el impacto de género que podría tener la supresión del pago de incentivos de productividad en cada uno de los permisos retribuidos del artículo 37.3 ET, a fin de determinar si ello pudiera suponer una merma de la efectividad del principio de igualdad de mujeres y hombres.

El análisis efectuado arroja las siguientes conclusiones. Por un lado, los permisos de matrimonio, fallecimiento de pariente, traslado de domicilio habitual, deber inexcusable de carácter público y personal y desempeño de funciones sindicales son neutros desde el punto de vista del género de las personas, pues afectan por igual a mujeres y hombres. Por lo tanto, la exclusión de los complementos de productividad del pago del salario en estos días de permiso no comporta ninguna discriminación o quiebra en el principio de igualdad por razón de sexo.

Ahora bien, en los permisos por accidente o enfermedad graves, hospitalización o intervención quirúrgica sin hospitalización que precise reposo domiciliario de parientes hasta el segundo grado de consanguinidad o afinidad, "sí que es de apreciar la concurrencia de circunstancias de género de las que se deriva una discriminación indirecta que debe ser corregida, en la medida en que las ausencias del puesto de trabajo en el uso de este permiso tienen mayor impacto en el colectivo de mujeres (...) que mayoritariamente son las que se hacen cargo de la atención a los familiares en esas circunstancias sobre un porcentaje menor de hombres" ${ }^{11}$. Para sostener esta tesis, apoyada en el desigual reparto de responsabilidades familiares "manifiestamente notorio y conocido en la realidad social" actual, el tribunal se remite a la Encuesta Nacional de Condiciones de Trabajo, 2015, publicada por el Observatorio Estatal de Condiciones de Trabajo (INSHT), a tenor de la cual las mujeres trabajadoras realizan en mayor medida que los hombres tareas de cuidados, educación y trabajo doméstico. Sin embargo, el Tribunal reconoce que no hay estadísticas específicas que verifiquen si los permisos por circunstancias familiares a los que se está haciendo referencia son disfrutados en mayor medida por las mujeres trabajadoras. A ello hay que añadir que en pronunciamientos anteriores el

\footnotetext{
${ }^{10}$ STS de 3 de diciembre de 2019, rec. 141/2018, f. j. $6^{\circ} .2$ y 3. Esta sentencia cita como precedente de su doctrina la STS de 6 de marzo de 2012 , rec. $80 / 2011$.

${ }^{11}$ Ibid., f. j. $7^{\circ}$.
} 
Tribunal Supremo ha afirmado que la finalidad de los permisos por accidente, enfermedad grave u hospitalización de un familiar no es necesariamente el cuidado directo del familiar ${ }^{12}$.

Respecto del permiso de asistencia a exámenes prenatales y técnicas de preparación al parto, la exclusión del complemento de productividad del cálculo de la remuneración constituye, a juicio del Tribunal Supremo, una "discriminación directa de las mujeres trabajadoras que no precisa de mayores razonamientos en atención a la finalidad de dicho permiso". El tribunal da por hecho que la titular de estos permisos es la trabajadora embarazada. Sin embargo, desde una perspectiva atenta a la corresponsabilidad de los futuros progenitores en el ámbito familiar, cabe entender que el otro progenitor también es titular de este derecho, tanto cuando se trate de asistencia o acompańamiento a los exámenes prenatales, como cuando la asistencia sea a los cursos de preparación al parto, cuyos destinatarios no son solo las mujeres embarazadas, sino también sus parejas. En todo caso, sí resulta muy probable que, con independencia de la titularidad indistinta que deben tener estos permisos, su uso en la práctica sea mayoritariamente femenino.

Por último, el Tribunal Supremo también considera discriminatoria la exclusión de incentivos de productividad de la remuneración de los permisos relacionados con la tramitación de adopción y guarda con fines de adopción o acogimiento, dadas las consecuencias negativas que podrían resultar para la corresponsabilidad familiar, como mecanismo de consecución de la igualdad efectiva por razón de sexo. A las razones anteriormente expuestas se añade un nuevo argumento: puesto que la pérdida del incentivo de productividad solo opera cuando la ausencia afecte a la totalidad de la jornada, se verán más perjudicadas las mujeres, al ser más alta la proporción de trabajadoras a tiempo parcial.

En definitiva, el tribunal sostiene que cuando se trate de permisos relacionados con el cuidado de familiares o con la maternidad o paternidad, no cabe excluir los incentivos por productividad del cálculo de la remuneración, so pena de incurrir en una vulneración del principio de igualdad por razón de sexo. Con toda probabilidad el razonamiento es válido para cualquier otro complemento salarial vinculado a la realización efectiva del trabajo.

Desde un punto de vista crítico, cabe indicar que, aunque el resultado alcanzado es muy acertado, deja en la sombra otros principios básicos dignos de tutela que actúan como fundamento de todos los permisos, también de aquellos que el tribunal califica como neutros desde el punto de vista del género. Así, los permisos por matrimonio, fallecimiento de familiar o traslado del domicilio habitual persiguen la conciliación de la vida laboral y familiar, que es un principio esencial del ordenamiento jurídico con relevancia constitucional ${ }^{13}$. Por su parte, el permiso para el cumplimiento de un deber inexcusable de carácter público y personal conecta con el derecho fundamental de los ciudadanos a participar en los asuntos públicos -artículo 23.1 CE- y el permiso para realizar funciones sindicales o de representación de los trabajadores es una manifestación de la libertad sindical -artículo $28 \mathrm{CE}-$. Si la exclusión de determinados complementos vinculados al trabajo efectivo de la remuneración correspondiente a los días de permiso vulnera el principio de igualdad por razón de sexo, habría que preguntarse si igualmente vulnera los principios y derechos mencionados en los permisos neutros por razón de sexo.

Por otro lado, la sentencia cuenta con un interesante voto particular en el que se aboga por el pago íntegro de las remuneraciones que corresponderían en caso de haber estado trabajando, sin

${ }^{12}$ La STS de 21 de septiembre de 2010, rec. 84/2009, sostiene que "su causa remota tampoco tiene por qué agotarse en el cuidado o atención personal, física y directa al familiar, porque la enfermedad o el ingreso hospitalario de éste puede requerir de aquél otro tipo de dedicación no directamente relacionada con la atención personal, que igualmente pueda justificar la ausencia al trabajo del primero" (f. j. $3^{\circ}$ ).

${ }^{13}$ Según el Tribunal Constitucional, las medidas orientadas a facilitar la conciliación de la vida familiar y laboral tienen una dimensión constitucional que se desprende de la lectura conjunta de los artículos 14 y 39 CE. Tal enfoque constitucional del derecho a la conciliación de la vida personal, familiar y laboral se enuncia en las SSTC 3/2007, de 15 de enero y 24/2011, de 14 de marzo, entre otras. 
hacer distinción entre tipos de permiso, pues "si el ejercicio del derecho (al disfrute del permiso) comporta minoración retributiva se produce cierto desincentivo o desaliento a quienes atraviesen por los supuestos legalmente tipificados como merecedores de la ausencia remunerada" ${ }^{\prime 4}$.

En conclusión, pese a tratarse de un pronunciamiento clarificador, no cabe dar por concluido el debate acerca de los elementos salariales que han de incluirse en la remuneración de los permisos, en especial por lo que se refiere a los permisos que el Tribunal Supremo califica como neutros desde un punto de vista de género.

Por otra parte, no hay que soslayar que la incidencia de los permisos sobre la retribución puede ser indirecta, como muestra la sentencia del Tribunal Supremo de 24 de febrero de 2006, en la que se debate si deben computarse como días trabajados, a efectos de generar el derecho a percibir un complemento salarial de trabajo en festivos, los domingos y festivos en los que, debiendo de prestar servicios, la persona trabajadora no lo ha hecho por disfrutar de un permiso retribuido. El Tribunal Supremo excluye que los días festivos comprendidos en el permiso tengan la consideración de días trabajados a efectos de generar el correspondiente complemento -que en el caso de autos comenzaba a cobrarse a partir del décimo festivo anual trabajado-, añadiendo además que el disfrute voluntario de los permisos corrobora esta conclusión. Por consiguiente, podría darse la circunstancia de que la coincidencia de uno o más permisos con días festivos planificados como de trabajo impida el cobro del complemento salarial previsto en el convenio, lo que supone, obviamente, una consecuencia salarial negativa derivada del uso de los permisos previstos a nivel legal o convencional ${ }^{15}$.

No obstante, el enfoque de género adoptado por la sentencia de 3 de diciembre de 2019 respecto de los permisos retribuidos obliga a modular esta doctrina del Tribunal Supremo. Así lo ha hecho una reciente sentencia de la Audiencia Nacional que considera que determinadas cláusulas convencionales que no cuentan como tiempo trabajado el correspondiente al disfrute de los permisos retribuidos, a efectos de calcular incentivos salariales, son discriminatorias por razón de sexo cuando se trata de permisos ligados al sexo de las personas o a roles de género, sea su origen legal o convencional ${ }^{16}$.

\section{Elementos esenciales de los permisos retribuidos}

Como ya se ha indicado, los permisos retribuidos tienen como finalidad exonerar a la persona trabajadora de la obligación de prestar servicios en un momento dado, al primar el ordenamiento jurídico la atención de otros menesteres de carácter personal, por regla general necesarios y urgentes. Por tanto, los elementos sobre los que pivota esta institución son dos: por un lado, la concurrencia de una causa descrita a nivel legal o convencional y, por otro lado, el efecto que puede desencadenar dicha causa, que es la exoneración del deber de trabajar ${ }^{17}$.

\footnotetext{
${ }^{14}$ Voto particular formulado por el Magistrado Excmo. Sr. D. Antonio V. Sempere Navarro, al que se adhiere la Magistrada Excma. Sra. Da Rosa María Virolès Piñol, a la sentencia del Pleno dictada en el recurso de casación no 141/2018.

${ }^{15}$ STS de 24 de febrero de 2006, rec. 119/2004, f. j. $8^{\circ}$.

${ }^{16}$ De hecho, la sentencia no solo se remite a los permisos señalados por el Tribunal Supremo en su sentencia de 3 de diciembre de 2019, sino que también extiende la tacha de discriminación a la exclusión del cómputo de las horas correspondientes a permisos acuñados por el convenio colectivo aplicable, como el permiso para "acompañar a hijos menores de 15 años a urgencia médica no previsible en horas coincidentes con el horario de trabajo" (SAN de 27 de abril de 2020, proc. 261/2019, f. j. 8).

En todo caso, como precedente a esta doctrina jurisprudencial recogida ya por la Audiencia Nacional hay que traer a colación la STS de 18 de mayo de 2016, rec. 140/2015, en la que se examina una cláusula convencional que excluía los días de absentismo justificado del tiempo de trabajo computable a efectos de ascender en los niveles de promoción económica. El Supremo, siguiendo el criterio previo de la Audiencia Nacional en el caso de autos, declara válida la exclusión del cómputo de los días de excedencia y permisos retribuidos, salvo cuando la causa del permiso o excedencia tenga relación con el derecho de igualdad y conciliación de la vida laboral y familiar o esté vinculada a otros derechos fundamentales (f. j. 7o).

${ }^{17}$ SÁNCHEZ TRIGUEROS, C., Los permisos retribuidos del trabajador (Régimen jurídico de las interrupciones no periódicas, preavisadas y justificadas del contrato de trabajo), cit., 30.
} 


\subsection{Adecuación entre la causa y el uso del permiso}

La exigencia de causalidad no se agota en la descripción legal o convencional de unas situaciones que justifican el derecho al permiso, sino que además comprende la adecuación de su uso a la causa que lo desencadena. En numerosas sentencias el Tribunal Supremo ha subrayado que los permisos no se conceden para la libre disposición, la holganza o el descanso de las personas trabajadoras, pues el uso de esta institución con dicha finalidad u otra que no tenga relación con la causa descrita en el ordenamiento o en el convenio colectivo constituiría un fraude o abuso de derecho merecedor del correspondiente reproche empresarial ${ }^{18}$. De ahí la exigencia de justificación con posterioridad a su disfrute. La justificación debe versar sobre la concurrencia de la causa desencadenante, sea de origen legal o convencional, pero en algunos casos también comprende el propio uso del permiso por parte de su titular, poniendo así de manifiesto que el vínculo entre la causa y el uso del permiso es más estricto en unos supuestos que en otros. O bien, desde otra perspectiva, que la causa no siempre cuenta con el mismo grado de amplitud y concreción, lo cual incide en la delimitación del uso del permiso.

Así, hay supuestos en los que la causa está vinculada a un uso muy concreto del permiso, hasta el punto de que este puede consistir en la exoneración del trabajo tan solo durante unas horas, las estrictamente necesarias para atender a la causa. Esto sucede, por ejemplo, con los permisos para asistir a exámenes prenatales o técnicas de preparación al parto, para realizar trámites preceptivos relacionados con la adopción o el acogimiento, o para el cumplimiento de un deber inexcusable de carácter público y personal. Estos permisos tienen una vinculación causal muy intensa y una causa bien delimitada, de modo que se extienden "por el tiempo indispensable"19. Además, el artículo 37.3.f) ET especifica que se tendrá derecho al permiso siempre que los exámenes prenatales, técnicas de preparación al parto o trámites relacionados con la adopción "deban tener lugar dentro de la jornada de trabajo”. Dado el tenor literal del precepto, la justificación suele exigir la acreditación de que no es posible realizar dichas gestiones fuera del horario de trabajo ${ }^{20}$.

En cambio, en los permisos de accidente, enfermedad grave y hospitalización de familiar, o intervención quirúrgica sin hospitalización, el vínculo entre la causa y el uso del permiso es objeto de una configuración algo más amplia. Así, el Tribunal Supremo ha señalado que la ley no establece como causa directa del beneficio el cuidado o atención personal que el trabajador haya de prestar al pariente enfermo. En otras palabras, "su causa remota tampoco tiene por qué agotarse en el cuidado o atención personal, física y directa al familiar, porque la enfermedad o el ingreso hospitalario de éste puede requerir de aquel otro tipo de dedicación no directamente relacionada con la atención personal, que igualmente pueda justificar la ausencia al trabajo" ${ }^{21}$. Por eso, en el caso de hospitalización de familiar el alta hospitalaria no determina de forma automática la desaparición de la causa que justifica el permiso y su correspondiente finalización, siendo posible continuar su disfrute aunque el familiar retorne a su domicilio, salvo que haya recibido el alta médica. En consecuencia, solo el alta médica, y no el alta hospitalaria, conduce a la finalización del permiso, pues acredita la conclusión de la situación patológica del familiar, que constituye la razón última del permiso ${ }^{22}$.

Por último, en el extremo opuesto, mostrando una mayor laxitud entre la concurrencia de causa legal y el uso del permiso, se encuentra el permiso por matrimonio, al que el ordenamiento

\footnotetext{
${ }^{18}$ STS de 21 de septiembre de 2010, rec. 84/2009, f. j. 30.

${ }^{19}$ Art. 37.3.d) y f) ET.

${ }^{20}$ BLASCO, C., Tiempo de trabajo y permisos del trabajador por motivos personales y sindicales, Tirant Lo Blanch, Valencia (2013) 64, 78 y RODRÍGUEZ ESCANCIANO, S., Los permisos parentales: avances y retrocesos tras las últimas reformas, cit., 33.

${ }^{21}$ STS de 21 de septiembre de 2010, rec. 84/2009, f. j. $3^{\circ}$.

22 Ídem. También SSTS de 13 de junio de 2018, rec. 128/2017, f. j. $2^{\text {o } ~ y ~ d e ~} 5$ de marzo de 2012, rec. 57/2011, f. j. $4^{\text {o }}$. Sobre el significado del término "hospitalización", a fin de concretar la causa del permiso, véase la reciente STS de 15 de julio de 2020, rcud. $11 / 2019$, f. j. $3^{\circ}$.
} 
atribuye una duración de quince días naturales. Su singularidad reside en que, con la salvedad del día en que se celebran las nupcias, no hay en sentido estricto un deber que necesite ser atendido de manera urgente por la persona trabajadora y que, por tanto, genere una incompatibilidad objetiva con el trabajo. Además, el hecho desencadenante, que es la boda, no tiene carácter sobrevenido, sino que su fecha es predeterminada por la persona trabajadora. Todo ello implica un menor nivel de urgencia o necesidad, si se lo compara con el resto de los permisos ${ }^{23}$.

Esta singularidad prácticamente elimina la relación entre la causa y el uso del permiso, que sin embargo resulta tan exigente en otras ocasiones, según se ha visto. Y es que, a pesar de que la realización de un viaje a continuación de las nupcias sigue siendo una práctica frecuente, en realidad no pesa sobre la persona trabajadora ninguna obligación jurídica de dedicar el tiempo del permiso por matrimonio a una actividad concreta, lo que produce la aproximación de este permiso a un tiempo de libre disposición.

Dejando de lado el análisis pormenorizado de cada permiso, conviene destacar que el vínculo entre la causa y el uso del permiso resulta clave para resolver algunos problemas que se pueden dar en la práctica, como la desaparición prematura de la causa antes de que concluyan los días de permiso o el hecho de que esta tenga lugar durante un periodo en el que no hay obligación de prestar servicios, por ejemplo, porque la relación laboral esté suspendida o porque coincida con vacaciones o días festivos.

Teniendo en cuenta todo lo anterior, parece claro que, si la causa desaparece antes de que se haya agotado la duración legal o convencional del permiso, se pierde el derecho a concluir su disfrute. Esta situación puede darse cuando se suceden los hechos causantes de varios permisos, en cuyo caso la doctrina ha entendido que el nacimiento de un nuevo permiso pone fin al anterior, aunque este no se haya disfrutado íntegramente ${ }^{24}$. Sin embargo, esta respuesta solo es válida cuando la causa del segundo hecho causante - por ejemplo, fallecimiento del familiar frente a su previa enfermedad grave, accidente u hospitalización- provoca la desaparición de la primera ${ }^{25}$. En cambio, si no hay ninguna relación entre la causa de los permisos que se suceden, el permiso posterior no tiene por qué poner fin al primero. Así, si el fallecimiento de un familiar se produce durante el disfrute del permiso por matrimonio, este no se agota, pues su causa no ha desaparecido. Problema distinto es si al finalizar uno de los permisos podrían disfrutarse los días correspondientes al otro, cuestión que se abordará más adelante.

\subsection{Razonable inmediación}

A la vista de todo lo dicho resulta evidente que el permiso solo tiene sentido cuando sirve para atender a la causa que lo genera, de ahí que la jurisprudencia exija una cierta inmediatez temporal entre el hecho causante del permiso y su efectivo disfrute ${ }^{26}$. Este concepto jurídico indeterminado cuenta con una amplia tradición, pues el Tribunal Central de Trabajo ya puso de manifiesto la necesidad de que concurriese una "razonable inmediación" entre el hecho desencadenante y el uso de la licencia, precisamente para preservar la causalidad de la institución ${ }^{27}$.

La expresión "razonable inmediación" evidencia que no es precisa una total coincidencia entre el hecho causante y el disfrute del permiso, sino que basta una proximidad temporal adecuada para

\footnotetext{
${ }^{23}$ SÁNCHEZ TRIGUEROS, C., Los permisos retribuidos del trabajador (Régimen jurídico de las interrupciones no periódicas, preavisadas y justificadas del contrato de trabajo), cit., 73.

${ }^{24}$ RODRÍGUEZ ESCANCIANO, S., Los permisos parentales: avances y retrocesos tras las últimas reformas, cit., 16.

${ }^{25}$ Otro ejemplo puede ser el permiso por matrimonio y el permiso por mudanza. Véase BLASCO, C., Tiempo de trabajo y permisos del trabajador por motivos personales y sindicales, cit., 55, 56.

${ }^{26}$ SSTS de 17 de marzo de 2020, rec. 193/2018, f. j. $2^{\circ}$ y de 11 de marzo de 2020, rec. 192/2018, f. j. $2^{\circ}$.

${ }^{27}$ STCT de 29 de agosto de 1983, y SÁNCHEZ TRIGUEROS, C., Los permisos retribuidos del trabajador (Régimen jurídico de las interrupciones no periódicas, preavisadas y justificadas del contrato de trabajo), cit., 52.
} 
que este último pueda cumplir su finalidad. Por lo tanto, una vez acaecido el hecho causante, el permiso debe disfrutarse en un momento suficientemente cercano para que la persona trabajadora pueda atender a las necesidades protegidas por la causa.

Con todo, no siempre es fácil determinar cuándo existe esa "razonable inmediación", pues no todos los permisos mantienen una relación igualmente estrecha o inmediata con el hecho causante. Entre los permisos que ofrecen menos dificultades para apreciar la razonable inmediación se encuentran los de asistencia a exámenes prenatales y técnicas de preparación al parto; asistencia a sesiones de información y preparación para la adopción, guarda con fines de adopción o acogimiento; así como fallecimiento o accidente de familiar. En todos ellos se da una situación más o menos sobrevenida que requiere la atención urgente de la persona trabajadora ${ }^{28}$.

Por el contrario, cuando las necesidades generadas por el hecho causante no consisten en un hecho puntual, sino que se extienden en el tiempo, o bien son menos urgentes, la determinación de la razonable inmediación no surge de modo tan evidente. Como ejemplo de ello se pueden mencionar los permisos por enfermedad grave y hospitalización de familiares. Teniendo en cuenta que ambas situaciones pueden tener una duración más o menos prolongada, se plantea la cuestión de cuándo se puede solicitar dicho permiso. Aunque en ocasiones se ha considerado que el permiso pretende atender al momento en el que la persona trabajadora conoce la gravedad de la patología, lo que excluye su disfrute en un momento posterior ${ }^{29}$, no parece esta una interpretación acorde con la necesaria conciliación de la vida laboral y familiar, cuyas particularidades pueden requerir la presencia de la persona trabajadora al lado del enfermo en momentos posteriores al inicio de su enfermedad, siempre que persistan las condiciones de gravedad y de hospitalización ${ }^{30}$.

Algo similar sucede respecto del permiso por traslado del domicilio, cuyo hecho causante no se identifica con la mudanza en sentido estricto, ni se limita a ella. Por tanto, el permiso podría tener lugar en cualquier momento razonablemente próximo al traslado efectivo en el que hubiese que realizar trámites $\mathrm{u}$ otras gestiones relacionadas con el cambio de domicilio habitual ${ }^{31}$.

Por último, también en el caso del permiso por matrimonio la razonable inmediación puede ser objeto de una interpretación más flexible, a pesar de que el hecho causante tiene carácter puntual, dada la menor urgencia objetiva en el disfrute del permiso, que hace que este pueda comenzar unos días antes o después de la ceremonia nupcial ${ }^{32}$. En todo caso, la jurisprudencia del Tribunal Supremo ha insistido en que la fecha del matrimonio ha de estar incluida dentro de los días de permiso, salvo cuando la celebración tenga lugar en día no laborable ${ }^{33}$.

${ }^{28}$ El Tribunal Supremo ha manifestado que el permiso de fallecimiento de familiar y el ya desaparecido permiso por nacimiento de hijo "tienen su causa en un acontecimiento que se produce de una sola vez, en un momento determinado. Y si los permisos de que tratamos tienen su causa y razón de ser en esta clase de acontecimientos, es totalmente lógico estimar que el disfrute de estos permisos tiene que hacerse efectivo en el tiempo inmediatamente siguiente a aquél en que tuvo lugar el correspondiente nacimiento o fallecimiento (...) si la licencia se hace realidad uno o varios meses después del nacimiento del hijo (o de la muerte del familiar), difícilmente puede afirmase que tal licencia se concede por este nacimiento o esta defunción. La razón de ser de estos permisos se debe a la gran importancia, muy especial significado y enorme carga de sentimientos y emociones que los referidos acontecimientos tienen para toda persona; de ahí que el disfrute de los mismos tenga que ser hecho efectivo en el momento en que tales sucesos acontecen, es decir, en el día en que se produjeron y en los inmediatos siguientes" (STS de 17 de enero de 2008, rec. 24/2007, f. j. 2o).

${ }^{29}$ SÁNCHEZ TRIGUEROS, C., Los permisos retribuidos del trabajador (Régimen jurídico de las interrupciones no periódicas, preavisadas y justificadas del contrato de trabajo), cit., 124.

${ }^{30}$ BLASCO, C., Tiempo de trabajo y permisos del trabajador por motivos personales y sindicales, cit., 48-50.

${ }^{31}$ STS de 7 de mayo de 1992, rec. 1755/1991, f. j. 30.

${ }^{32}$ SÁNCHEZ TRIGUEROS, C., Los permisos retribuidos del trabajador (Régimen jurídico de las interrupciones no periódicas, preavisadas y justificadas del contrato de trabajo), cit., 85 y BLASCO, C., Tiempo de trabajo y permisos del trabajador por motivos personales $y$ sindicales, cit., $25,26$.

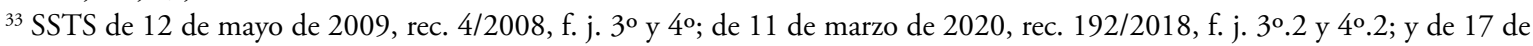
marzo de 2020, rec. 193/2018, f. j. $4^{\circ}$. 
No obstante, el Tribunal Supremo ha admitido que la negociación colectiva pueda optar por una interpretación más generosa de la razonable inmediación, flexibilizando el nexo entre el acaecimiento del hecho causante y el momento de disfrute del derecho, pues ello constituye una mejora del régimen legal de los permisos y, como ya se ha indicado, el artículo $37.3 \mathrm{ET}$ es un precepto imperativo de derecho necesario relativo ${ }^{34}$. Sin embargo, para que este tipo de cláusulas sean válidas es preciso que se cumplan ciertos requisitos. En primer lugar, que no conduzcan a una desnaturalización de los permisos, que se produciría cuando su disfrute retardado ya no respondiese a la causa legal o convencional, sino a otras diferentes, aunque pudieran tener vinculación o conexión con aquélla. En segundo lugar, que el tenor literal de la disposición negociada refleje expresa y claramente la posibilidad de posponer el disfrute del permiso, pues si no se dice nada al respecto no puede admitirse su cumplimiento tardío, ya que ello va en contra de la propia causa y naturaleza del mismo. En tercer y último lugar, el Tribunal Supremo advierte de que solo puede admitirse el cumplimiento tardío de esta clase de permisos si la norma que los regula fija el plazo o límite temporal dentro del cual es posible efectuar ese cumplimiento; es decir, será preciso determinar un período de tiempo durante el que el permiso puede llevarse a efecto, siendo totalmente inaceptable el establecimiento de tal cumplimiento tardío sin límite temporal alguno ${ }^{35}$.

Muestra de este tipo de disposiciones es, por ejemplo, una cláusula de un convenio colectivo que establece que el disfrute de los permisos podrá iniciarse dentro de los diez días naturales siguientes al acaecimiento del hecho causante. La comedida separación entre el hecho causante y el disfrute del permiso, así como la clara acotación del periodo dentro del cual deberá comenzar tal disfrute apoyan la validez de la disposición, que no quiebra la causalidad ni la razonable inmediación propias de esta institución ${ }^{36}$.

\subsection{La exoneración del deber de trabajar}

Junto con la causa, la exoneración del deber de trabajar es el otro elemento esencial de los permi$\operatorname{sos}^{37}$. La presencia de dicho requisito se desprende de la lógica interna de esta institución, cuya finalidad es precisamente liberar a las personas trabajadoras de la obligación de prestar servicios cuando concurren circunstancias relevantes, casi siempre de orden personal o familiar, cuya atención resulta incompatible con el trabajo.

A partir de esta premisa, el solapamiento entre el trabajo y el hecho desencadenante del permiso parece configurarse como un requisito necesario para su uso. De hecho, como ya se ha destacado, algunos permisos del artículo 37.3 ET referidos a gestiones puntuales y de duración limitada requieren incluso la coincidencia horaria del hecho causante con la jornada de trabajo ${ }^{38}$. Esta exigencia podría afectar de manera negativa a las personas adscritas a horario nocturno, pues difícilmente el hecho causante tendrá lugar dentro de su horario de trabajo, con la consiguiente reducción de sus posibilidades de hacer uso de los citados permisos, debiendo afrontar dichas activi-

\footnotetext{
${ }^{34}$ STS de 29 de marzo de 2017, rec. 61/2016, f. j. $4^{\circ}$.

${ }^{35}$ STS de 17 de enero de 2008, rec. 24/2007, f. j. $2^{\circ}$.

${ }^{36}$ En el caso de autos, los permisos cuyo inicio podía diferirse eran los de fallecimiento de cónyuge, pareja de hecho o familiar hasta el segundo grado de consanguinidad o afinidad; de accidente, enfermedad grave, intervención quirúrgica u hospitalización del de cónyuge, pareja de hecho o familiar hasta el segundo grado de consanguinidad o afinidad y el de traslado del domicilio habitual (STS de 29 de marzo de 2017, rec. 61/2016, f. j. 4º).

${ }^{37}$ El Tribunal Supremo subraya esta vertiente llamando la atención sobre el tenor literal del artículo 37.3 ET que, al regular el descanso semanal, las fiestas y los permisos retribuidos dispone que "el trabajador... podrá ausentarse del trabajo con derecho a remuneración" (STS de 13 de febrero de 2018, rec. 266/2016, f. j. 2º).

${ }^{38}$ Art. 37.3.d) y f) ET.
} 
dades en su tiempo libre y de descanso. El Tribunal Supremo ha corregido la excesiva rigidez de esta regla respecto de los permisos por razones sindicales del artículo 37.3.e) ET y en general respecto del crédito horario, configurando una excepción a tenor de la cual los representantes sindicales con horario o turno nocturno tendrán derecho al permiso, aunque sus funciones no deban ser desempeñadas dentro de su horario de trabajo, pues de otro modo se dificultaría en extremo y de forma injustificada el ejercicio de la actividad sindical que, como el propio Tribunal subraya, no responde a un interés privado, sino que tiene una relevancia social digna de especial protección ${ }^{39}$.

Pese a todo, no es infrecuente que el hecho causante tenga lugar en un periodo en el que, aunque la relación laboral esté vigente, no haya obligación de trabajar. Esas situaciones plantean numerosas incógnitas respecto del uso de los permisos que el Tribunal Supremo ha tenido ocasión de despejar en los últimos meses.

\section{El solapamiento de los permisos con otros tiempos en los que no concurre el deber de pres- tar servicios}

Como se acaba de indicar, aunque la relación laboral continúe vigente, hay determinados momentos o periodos en los que se interrumpe de forma temporal la obligación de trabajar. Ello puede suceder a causa de los descansos semanales, los días festivos, las vacaciones, otros permisos o licencias, las suspensiones del contrato de trabajo o las excedencias. Pero también hay que tener en cuenta que no todas las personas trabajan cinco o seis días a la semana o todos los días fijados como laborables en el calendario de la empresa. Ello sucede de forma más acusada cuando el trabajo se realiza a tiempo parcial.

Pues bien, si el hecho causante del permiso acaece durante cualquiera de estas interrupciones de la obligación de prestar servicios se pueden plantear dos situaciones que a su vez dan lugar a diversas preguntas.

En primer lugar, si el solapamiento entre el permiso y la previa interrupción de la relación laboral es total, es decir, la interrupción previa es más amplia que la duración del permiso, hay que plantearse si los días de permiso pueden ser disfrutados una vez que haya concluido la interrupción de la relación laboral o si, por el contrario, la institución del permiso no debe operar en estos supuestos, dado que, ciertamente, no se plantea el conflicto entre el trabajo y la atención de deberes extralaborales que constituye su razón de ser.

En segundo lugar, cuando el solapamiento entre el permiso y la previa interrupción de la relación laboral es parcial, las preguntas se refieren a su cómputo. Así, no solo hay que determinar cuándo debe iniciarse el disfrute del permiso, especialmente si el hecho causante sucede cuando no hay obligación de prestar servicios, sino también si los días en que sobreviene el solapamiento computan como días de permiso o no.

\subsection{La coincidencia de los permisos con vacaciones y descanso semanal ante el Derecho de la Unión Europea. El asunto Fetico}

La polémica entre el solapamiento de los permisos retribuidos del artículo 37.3 ET y los periodos de vacaciones $\mathrm{u}$ otros descansos ha adquirido recientemente una relevancia especial al dar lugar al

${ }^{39}$ STS de 18 de marzo de 1986, f. j. 2º, RJ\1986\1347. En el mismo sentido, STS de 3 de julio de 1989, f. j. 1º, RJ\1989\5423. 
planteamiento de una cuestión prejudicial resuelta por el Tribunal de Justicia de la Unión Europea en su sentencia de 4 de junio de $2020^{40}$.

La cuestión prejudicial planteada por la Audiencia Nacional contempla el solapamiento entre el hecho causante de los permisos retribuidos y las vacaciones o descansos desde una perspectiva diferente a las anteriormente expuestas, que se centra en la posibilidad real de hacer efectiva la finalidad de ambas instituciones. En efecto, según la Audiencia, "si se produce cualquiera de los acontecimientos previstos por la normativa nacional durante los períodos de descanso semanal o de vacaciones anuales retribuidas, se superpondrían dos imperativos diferentes, a saber, el descanso que estos períodos persiguen garantizar a los trabajadores y la necesidad o la obligación de que trae causa el permiso retribuido de que se trate contemplado por dicha normativa. $\mathrm{Si}$, en tal caso, no cupiera la posibilidad de diferir el disfrute del permiso retribuido a un momento distinto de los referidos períodos, estos últimos se vaciarían de contenido, puesto que los trabajadores tendrían que dedicarlos a atender a las necesidades y obligaciones para las que están previstos los permisos retribuidos" ${ }^{41}$. A juicio de la Audiencia Nacional, la imposibilidad de disfrutar de los días de permiso una vez concluido el periodo de descanso podría colisionar con los artículos 5 y 7 de la Directiva 2003/88/CE del Parlamento Europeo y del Consejo, de 4 de noviembre de 2003, relativa a determinados aspectos de la ordenación del tiempo de trabajo, en los que se regulan el descanso semanal y las vacaciones anuales, respectivamente, al interferir en la consecución de su finalidad, que es la recuperación física y psicológica tras un periodo de trabajo, así como el ocio y el esparcimiento.

Es evidente que la Audiencia Nacional tiene en cuenta la asentada y muy relevante doctrina del Tribunal de Justicia relativa al solapamiento entre las vacaciones y el permiso por maternidad o la incapacidad temporal para comprobar si parte de ese razonamiento puede aplicarse a la situación planteada en la cuestión prejudicial. Pero, aparte de las consideraciones que hace en la sentencia el Tribunal de Justicia, hay que llamar la atención sobre una diferencia fáctica entre tales supuestos, pues mientras el solapamiento entre las vacaciones y las suspensiones por maternidad o por incapacidad temporal produciría como resultado la imposibilidad de disfrutar de las vacaciones, que quedarían subsumidas en las bajas, de no aplicarse la doctrina correctora del Tribunal de Justicia, en el caso de la coincidencia entre las vacaciones y los permisos retribuidos es esta última institución la que queda anulada por la primera, y no al revés. Y es que el disfrute de los días de vacaciones no se ve afectado, al menos formalmente aunque, como plantea la Audiencia Nacional, su finalidad pueda verse menoscabada por la atención de las necesidades relacionadas con los permisos.

En síntesis, la respuesta del Tribunal de Justicia, que descarta una colisión entre el Derecho interno y el Derecho de la Unión Europea, se articula en torno a dos ejes mediante los cuales se pretende destacar las particularidades que impiden aplicar a este supuesto las soluciones arbitradas respecto de las bajas por maternidad, por un lado, y las bajas por incapacidad temporal, por otro.

Así, el Tribunal reconoce que de su reiterada jurisprudencia en torno a la coincidencia del periodo de baja por maternidad con las vacaciones "se desprende que un permiso garantizado por el Derecho de la Unión no puede menoscabar el derecho a disfrutar de otro permiso garantizado por ese mismo Derecho con distinta finalidad que el primero"42. Ahora bien, esta doctrina no es aplicable al caso planteado por la Audiencia Nacional porque los permisos retribuidos previstos por la normativa legal y convencional invocada no forman parte del Derecho de la Unión Europea, que no los incluye en la Directiva 2003/88/CE, y por tanto son fruto del ejercicio de las competencias exclusivas de un Estado miembro ${ }^{43}$.

\footnotetext{
${ }^{40}$ STJUE (Gran Sala) de 4 de junio de 2020, asunto C-588/18, Fetico y otros.

${ }^{41}$ Ibid., apartado 22.

${ }^{42}$ Ibid., apartado 40.

${ }^{43} \mathrm{Ibid}$., apartado 31.
} 
Ni siquiera podría aplicarse esta doctrina si se considerase que el permiso por enfermedad o accidente de familiar recogido en la normativa interna está comprendido en el ámbito de aplicación de la Directiva 2010/18/UE del Consejo, de 8 de marzo de 2010, por la que se aplica el Acuerdo marco revisado sobre el permiso parental -ya derogada, pero aplicable al caso por razones temporales-. Y ello porque el derecho a ausentarse del trabajo por fuerza mayor en caso de enfermedad o accidente de familiar previsto en la cláusula 7.1 del Acuerdo Marco no puede asimilarse a un permiso, en el sentido que le atribuye la jurisprudencia del Tribunal de Justicia ${ }^{44}$.

Pero, el hecho de descartar la aplicación de la jurisprudencia sobre el solapamiento de dos permisos garantizados por el Derecho de la Unión a la cuestión prejudicial planteada no implica la automática resolución de la misma, pues, como recuerda el Tribunal, el ejercicio de las competencias propias por parte de los Estados miembros no puede menoscabar el Derecho de la Unión Europea, concretado en este caso en el disfrute efectivo de los períodos mínimos de descanso semanal y de vacaciones anuales retribuidas previstos en los artículos 5 y 7 de la Directiva 2003/88/CE ${ }^{45}$. Es decir, el Tribunal pretende comprobar ahora si el argumento utilizado para resolver el solapamiento entre las vacaciones y las bajas por incapacidad temporal -que no son objeto de regulación en el Derecho de la Unión- se puede aplicar a la cuestión planteada por la Audiencia Nacional.

El Tribunal responde negativamente a esta segunda cuestión con base en un elemento constitutivo de los permisos que, como se verá, también ha de ser determinante en la respuesta aportada por el Tribunal Supremo a los conflictos entre el disfrute de los permisos y las vacaciones. Se trata de la exoneración del deber de trabajar como finalidad y efecto principal de esta institución. Así, el Tribunal de Justicia indica que "en la medida en que únicamente tienen por objeto permitir a los trabajadores ausentarse del trabajo para atender a ciertas necesidades $\mathrm{u}$ obligaciones determinadas que requieren de su asistencia personal, los permisos retribuidos contemplados en las disposiciones controvertidas en los litigios principales están indisociablemente ligados al tiempo de trabajo como tal, de modo que los trabajadores no pueden reclamarlos en períodos de descanso semanal o de vacaciones anuales retribuidas" 46 .

Esta característica, además, diferencia a los permisos retribuidos de la baja por incapacidad temporal e impide aplicar la jurisprudencia elaborada en torno al solapamiento de la misma con las vacaciones ${ }^{47}$.

En definitiva, los artículos 5 y 7 de la Directiva 2003/88/CE, que regulan los períodos de descanso semanal y de vacaciones anuales retribuidas, no "obligan a un Estado miembro cuya normativa nacional contempla el disfrute de permisos retribuidos a concederlos por el mero hecho de que alguno de los acontecimientos contemplados en esta normativa acaezca en alguno de estos períodos, y por lo tanto haciendo caso omiso de los demás requisitos de obtención y concesión establecidos por dicha normativa” ${ }^{4}$.

A la vista de todo lo anterior, el Tribunal concluye que el Derecho de la Unión Europea no es aplicable al supuesto planteado por la Audiencia Nacional. Por tanto, la problemática derivada del solapamiento del hecho causante de los permisos con periodos de descanso ha de ser resuelta a nivel nacional, conforme a las normas legales y convencionales que conforman el ordenamiento jurídico interno.

\footnotetext{
${ }^{44}$ Ibid., apartado 41.

${ }^{45}$ Ibid., apartados 32 a 34 .

${ }^{46} \mathrm{Ibid}$., apartado 36.

${ }^{47}$ Ibid., apartado 36.

${ }^{48} \mathrm{Ibid}$., apartado 38.
} 


\subsection{La coincidencia de los permisos con suspensiones y vacaciones: posición de los tribunales internos}

La concurrencia de causas de permiso retribuido durante un periodo en el que la relación laboral se encuentra suspendida en virtud del artículo $45 \mathrm{ET}$ no ha sido fuente de una litigiosidad significativa en el ámbito interno. Hay que recordar que durante la suspensión dejan de aplicarse las obligaciones principales del contrato de trabajo - prestar servicios y retribuirlos-, manteniéndose únicamente algunas obligaciones accesorias. Esta configuración legal de la suspensión hace difícil que dentro de ella pueda operar la institución de los permisos. Además, el principio de razonable inmediación obstaculiza la tesis de que pueda retrasarse el disfrute del permiso hasta el momento en que concluya la suspensión si la separación temporal desvirtúa la causa por la que este se concede. A pesar de todo, alguna sentencia dictada en suplicación se ha pronunciado sobre las consecuencias jurídicas de la coincidencia entre el matrimonio -hecho causante del permiso regulado en el artículo 37.3.a) ET - y la suspensión del contrato de trabajo por maternidad.

En efecto, la sentencia del TSJ de Andalucía de 22 de febrero de 2008 examina el caso de una trabajadora que contrae matrimonio durante su baja por maternidad y que, al reincorporarse a su puesto de trabajo, más de un mes después del hecho causante, solicita los días de permiso correspondientes, petición que es rechazada por la empresa. De forma escueta pero muy contundente el Tribunal señala que "la situación de maternidad, en modo alguno, puede producir un perjuicio para la madre trabajadora, de forma tal que, finalizado el correspondiente periodo de suspensión del contrato por esta causa, tiene derecho a disfrutar del permiso de matrimonio", invocando en apoyo de esta conclusión el artículo 8 de la Ley Orgánica 3/2007, de 22 de marzo, para la igualdad efectiva de mujeres y hombres que establece que "constituye discriminación directa por razón de sexo todo trato desfavorable a las mujeres relacionado con el embarazo o la maternidad"49.

Al centrar su razonamiento en el principio de igualdad y no discriminación el Tribunal no se plantea dos cuestiones que posiblemente hay que tener en cuenta, como son el juego de la causalidad o la razonable inmediación en este tipo de supuestos, por un lado, y si verdaderamente la falta de disfrute del permiso en tales circunstancias constituye un perjuicio para la persona trabajadora, por otro lado.

En todo caso, la reflexión sobre tales cuestiones debe tener en cuenta la singularidad del permiso por matrimonio desde el punto de vista causal, en comparación con el resto de los permisos. Como ya se ha indicado, en el permiso por matrimonio la relación entre la causa y el uso de permiso se diluye pues, aunque su finalidad es facilitar la celebración de la ceremonia y el inicio de la vida conyugal, no hay una exigencia legal de dedicar el tiempo del permiso a una actividad concreta, lo que lo aproxima a unos días de libre disposición o de vacaciones, a pesar de que el Tribunal Supremo ha manifestado de forma insistente que estas instituciones no son identificables pues persiguen finalidades muy diferentes ${ }^{50}$. Además, ese carácter inespecífico del uso del permiso tiende a reducir la urgencia respecto de su disfrute, de modo que, si bien lo habitual y ordinario es que este se produzca a continuación del hecho causante, no parece contrario a la lógica ni al principio de razonable inmediación que el disfrute pueda posponerse unos días o semanas, por voluntad de la persona trabajadora ${ }^{51}$.

Estas consideraciones explican el pronunciamiento del TSJ de Andalucía, que no solo no se plantea la pervivencia de la causa que da lugar al permiso tras mes y medio desde la celebración

\footnotetext{
${ }^{49}$ STSJ de Andalucía de 22 de febrero de 2008, rec. 4402/2006, f. j. único.

${ }^{50}$ SSTS de 3 de diciembre de 2019, rec. 192/2018, de 11 de marzo de 2020, rec. 192/2018, f. j. $2^{\circ}$ y de 17 de marzo de 2020, rec. $193 / 2018$, f. j. $2^{\circ}$.

${ }^{51}$ Alguna sentencia dictada en suplicación adopta a este respecto un criterio extraordinariamente amplio que probablemente no se ajuste a la jurisprudencia del Tribunal Supremo. Véase al respecto la STSJ de La Rioja de 9 de febrero de 2010, rec. 31/2010, f. j. $3^{\circ}$.
} 
de las nupcias, sino que concibe la negativa de la empresa a conceder los días de permiso como un perjuicio para la trabajadora, como si se tratase de días de vacaciones o de libre disposición.

Si bien el razonamiento del órgano judicial puede tener cierto encaje respecto del permiso por matrimonio, es dudoso que pueda mantenerse respecto de otros permisos cuyo hecho causante hubiera acaecido durante la suspensión del contrato de trabajo por maternidad, como por ejemplo los permisos por fallecimiento o accidente de familiar. Dado el carácter más estricto de la causa en estos últimos permisos, no parece que pudiera defenderse el derecho de la trabajadora a disfrutar de los días correspondientes tras la finalización de la baja por maternidad, considerando que lo contrario comportaría un perjuicio derivado de la situación de maternidad.

Problemas similares se han dado cuando el hecho causante de los permisos sucede mientras la persona trabajadora se encuentra de vacaciones, con la diferencia de que son más numerosas las sentencias que abordan esta cuestión, ya que el hecho de que la relación laboral no esté suspendida permite plantearse con mayor facilidad la pregunta acerca del disfrute de los permisos en estos supuestos. Las sentencias dictadas en suplicación no son unánimes en sus respuestas, que dependen del tipo de permiso del que se trate, de su regulación legal o convencional y del momento en que se produce el hecho causante del permiso. Con todo, como regla general los tribunales han sido estrictos en la consideración del principio de razonable inmediación entre el hecho causante y el momento del disfrute del permiso, lo que les ha llevado a denegar este último cuando, a causa del transcurso de las vacaciones, la separación temporal entre ambos sea amplia ${ }^{52}$. Este criterio se relaja en algunas sentencias en las que el hecho causante tiene lugar en el periodo final de las vacaciones, tratándose de circunstancias familiares urgentes motivadas por fallecimiento, enfermedad grave o accidente ${ }^{53}$.

Aunque hasta ahora el Tribunal Supremo no había tenido ocasión de terciar en este debate, en varias sentencias recientes ha realizado unas breves consideraciones que, sin embargo, por su firmeza y claridad, zanjan esta cuestión. Así, el Tribunal parte de la exoneración de la obligación de prestar servicios, como finalidad prioritaria de los permisos, y del principio de razonable inmediación para concluir que "la "ausencia del trabajo" solo está justificada cuando efectivamente hay obligación de trabajar, que no en los periodos de vacaciones o suspensión del contrato en los que no existe la obligación de acudir al puesto de trabajo". De esta manera se excluye la posibilidad de intercalar días de permiso en el periodo de disfrute de las vacaciones. Pero, además, añade sin ulteriores explicaciones que por ello "tampoco pueden diferirse para un momento posterior en el que se hubiera reanudado la prestación laboral”, pues durante cada uno de los días de permiso debe subsistir la situación de necesidad que lo justifica ${ }^{54}$. Así pues, el Tribunal opta por una interpretación restrictiva muy apegada a la finalidad de los permisos y a sus exigencias de causalidad.

A pesar de todo, hay que tener presente la capacidad de la negociación colectiva para mejorar este régimen mediante el establecimiento de pautas para la resolución de los conflictos que puedan darse cuando el hecho causante de todos o algunos permisos tenga lugar en periodos de suspensión del contrato de trabajo o de descanso ${ }^{55}$. El único límite impuesto a la libertad negocial consiste en

${ }^{52}$ SSTSJ de Galicia de 30 de mayo de 2008, rec. 1276/2008, f. j. 4º, y de Cataluña de 18 de junio de 2002, rec. 7823/2001, f. j. $2^{\circ}$.

${ }^{53}$ STSJ de Cataluña de 15 de septiembre de 2003, rec. 4493/2003, f. j. $2^{\circ}$.

${ }^{54}$ STS de 17 de marzo de 2020, rec. 193/2018, f. j. $2^{\circ}$ in fine y STS de 11 de marzo de 2020, rec. 192/2018, f. j. $2^{\circ}$ y $3^{\circ}$. En ambas sentencias el Tribunal Supremo se refiere al permiso por matrimonio, circunscribiendo su doctrina sobre el dies a quo a los supuestos en que este "se celebre en un momento en que la relación laboral despliegue plenos efectos y no se encuentre suspendida ni en periodo vacacional", pues de concurrir una "interrupción significativa del contrato de trabajo" el permiso no se podría ejecutar "y mucho menos diferir ... para un momento posterior en el que se hubiera reanudado la relación laboral". Así pues, en caso de que el permiso de matrimonio se solape con una suspensión del contrato de trabajo o con las vacaciones, el derecho al permiso no se iniciará, sino que quedará subsumido en el periodo de vacaciones o de suspensión contractual. En todo caso, aunque el Tribunal Supremo no lo advierte, el convenio colectivo podría modificar estos efectos, estableciendo una disposición más favorable.

${ }^{55}$ BLASCO, C., Tiempo de trabajo y permisos del trabajador por motivos personales y sindicales, cit., 27. 
no desnaturalizar la finalidad de los permisos regulados en el artículo 37.3 ET, como ya se ha señalado $^{56}$. En cuanto a los permisos creados por la propia negociación colectiva, la libertad para regular su momento de disfrute es absoluta.

\subsection{La coincidencia del permiso con días no laborales}

4.3.A. La reciente doctrina del Tribunal Supremo sobre el dies a quo para el cómputo de los días de permiso

La controversia jurídica que ha acaparado mayor atención en los últimos años es la relativa a la determinación del día inicial del cómputo de los días de permiso.

Es decir, en este caso no se plantea que el disfrute del permiso no resulte posible al quedar subsumido en un periodo de mayor amplitud en el que no concurra la obligación de trabajar, como una suspensión contractual o las vacaciones, tal y como se acaba de examinar. Por el contrario, lo que se plantea es que el hecho causante se produzca durante un periodo corto de no trabajo que no rompe el principio de razonable inmediación, pero que arroja dudas en torno al momento en que debe iniciarse el cómputo de los días de permiso ${ }^{57}$. El supuesto de hecho más evidente consiste en la coincidencia del hecho causante con el descanso semanal o con días festivos o no laborales, aunque el mismo problema podría plantearse cuando el hecho causante tiene lugar los últimos días de un descanso más amplio, como las vacaciones.

Como regla general, cuando el hecho causante sobreviene en un día laborable se toma como dies a quo ese mismo día, o bien, dependiendo del caso, el día siguiente ${ }^{58}$. Todo ello dejando a salvo la posibilidad de que el convenio colectivo establezca otras reglas relativas al cómputo que constituyan una mejora del régimen legal del artículo 37.3 ET y que no desnaturalicen la institución, que debe mantener su carácter causal.

Ahora bien, el problema se da cuando el mismo día en que se produce el hecho causante o el día siguiente el trabajador no tiene obligación de prestar servicios. En este supuesto las alternativas para la determinación del dies a quo son dos: o bien se aplica la regla general según la cual el cómputo del permiso comienza el día en que tiene lugar el hecho causante o al día siguiente, con independencia de que esos días no haya obligación de prestar servicios; o bien se inicia el cómputo del permiso el primer día laborable tras el hecho causante.

Este debate ha tenido mayor trascendencia práctica que los señalados en los apartados anteriores pues, dada la cadencia con la que se intercalan los días de trabajo con los días de descanso semanal, festivos u otros días no laborables, no resulta infrecuente que los hechos causantes se produzcan en estos últimos. De hecho, en algunos casos lo habitual que es que tengan lugar en ellos, como sucede con el matrimonio, cuya celebración suele coincidir con el descanso semanal. Además,

\footnotetext{
${ }^{56}$ Precisamente, apoyándose en la citada capacidad de la negociación colectiva y en la interpretación del convenio aplicable, alguna sentencia dictada en suplicación reconoció el derecho a disfrutar del extinto permiso por nacimiento de hijo a pesar de que éste hubiese tenido lugar durante las vacaciones o suspensiones del contrato de trabajo (STSJ de Galicia de 23 de noviembre de 2015, rec. 3684/2015, f. j. $2^{\circ}$ ). Otras veces los convenios son más claros a la hora de establecer de forma indubitada la posibilidad de acumular vacaciones y permisos. Así sucede con frecuencia con el permiso de matrimonio que, como ya se ha dicho, es el que menos objeciones despierta en cuanto a su disfrute aplazado, dada su similitud con un periodo de libre disposición. Véase, como ejemplo de ello, el artículo 58.a) del III Convenio colectivo de la Sociedad Estatal Correos y Telégrafos, SA., BOE núm. 153, de 28 de junio de 2011, que indica que si el permiso por coincide con algún periodo vacacional "se disfrutará seguido de aquél".

${ }^{57} \mathrm{La}$ compatibilidad del principio de razonable inmediación con la posibilidad de posponer el dies a quo al siguiente día laborable en caso de coincidencia de la ceremonia con días libres del trabajador ya fue señalada por la STS de 12 de mayo de 2009, rec. $4 / 2008$, f. j. $4^{\circ}$.

${ }^{58}$ STS de 11 de marzo de 2020, rec. 192/2018, f. j. $3^{\circ}$.
} 
el modo de determinar el dies a quo tiene consecuencias relevantes tanto para el trabajador como para la empresa. Así, si el cómputo se inicia al día siguiente del hecho causante, incluso cuando este sea festivo, la persona trabajadora dispondrá de menos días de no trabajo, al solaparse el permiso con otros días en los que ya concurría la exoneración de trabajar, y el permiso implicará un menor coste económico para la empresa. Por el contrario, si el dies a quo coincide con el primer día laborable, la persona trabajadora disfrutará íntegramente sus días de permiso y sus días no laborables y, por su parte, la empresa afrontará un mayor coste económico al tener que retribuirlos todos.

La trascendencia práctica de este asunto no solo se aprecia en el mayor volumen de litigios planteados en el ámbito judicial, sino también en el debate suscitado entre la Audiencia Nacional y el Tribunal Supremo, que han mantenido criterios y argumentaciones parcialmente diferentes, dada la parquedad del artículo $37.3 \mathrm{ET}^{59}$. Incluso la interposición de una cuestión prejudicial ante el Tribunal de Justicia, con la subsiguiente sentencia Fetico, ya analizada, ha venido impulsada por dicha controversia. En todo caso, de los diversos pronunciamientos del Tribunal Supremo durante los primeros meses de 2020 emerge una línea jurisprudencial clara que pone fin a tales disquisiciones.

La jurisprudencia del Tribunal Supremo sobre el dies a quo de los permisos retribuidos del articulo 37.3 ET se articula en torno a dos vertientes. La primera se refiere a la interpretación del precepto legal y, por extensión, de todos aquellos preceptos convencionales que reproducen sin modificación el tenor del artículo 37 ET. La segunda pretende aclarar lo que puede hacer la negociación colectiva respecto de la determinación del dies a quo.

Por lo que se refiere a la primera cuestión, hay que destacar que la posición firmemente mantenida por el Tribunal en diversas sentencias dictadas en marzo del 2020 ya se aprecia en algunas sentencias anteriores, lo que evidencia que la posición del Tribunal no es tan novedosa como pudiera parecer. Ahora bien, cierto es que los anteriores pronunciamientos, uno del 2009 y el otro de 2018, por su carácter aislado, no conformaban jurisprudencia en sentido estricto y tampoco contenían explicaciones tan exhaustivas como las que proporcionan las recientes sentencias ${ }^{60}$.

Pues bien, tanto en estos precedentes como en las sentencias dictadas en marzo de 2020 el Tribunal Supremo toma como elemento clave para interpretar cuál debe ser el dies a quo de los permisos cuyo hecho causante acaece en festivo la exoneración del deber de trabajar, que constituye, como ya se ha indicado, el principal efecto y la finalidad de esta institución.

Partiendo de este elemento, la argumentación es así de simple: los permisos se conceden para ausentarse del trabajo en día laborable, pues en día no laborable no hace falta solicitar un permiso, ya que la ausencia del trabajo solo está justificada cuando efectivamente hay obligación de trabajar. Por consiguiente, si el día en que se produce el hecho causante no es laborable resulta claro que no puede iniciarse el permiso, que solo comenzará a materializarse el primer día laborable que le siga. Además, en apoyo de esta conclusión el Tribunal señala que, de iniciarse el cómputo en día no

\footnotetext{
${ }^{59}$ Este debate ha sido objeto de análisis por parte de la doctrina científica. Véase al respecto SÁNCHEZ TRIGUEROS, C., “¿Puede posponerse el disfrute de los permisos por razones familiares al momento en que se debería trabajar? Comentario a la Sentencia del Tribunal Supremo 145/2018, de 13 de febrero", Revista de Trabajo y Seguridad Social. CEF, no 424 (2018) 135-141; MUNOZ RUIZ, A. B., "El cómputo de los permisos retribuidos: una revisión de la doctrina judicial y de la reciente cuestión prejudicial", Trabajo y Derecho, no 53 (2019) 45-56; GONZÁLEZ GONZÁLEZ, C., "La fecha inicial de disfrute de los permisos retribuidos. A propósito de la Sentencia del Tribunal Supremo n. ${ }^{\circ}$ 145/2018, de 13 febrero", Revista Aranzadi Doctrinal, 7 (2018) 129-141 y, del mismo autor, "Permisos retribuidos y reglas aplicativas sobre el cómputo de los días de disfrute", Revista Aranzadi Doctrinal, 7 (2019); BASTERRA HERNÁNDEZ, M., "Últimas novedades jurisprudenciales en torno a los permisos retribuidos. El dies a quo para el cómputo de los permisos retribuidos del art. 37.3 del ET y la acumulación del permiso de lactancia para su disfrute en jornadas completas", Trabajo y Derecho, no 46 (2018) 85-92; PEÑA MONCHO, J., "El inicio y cómputo de los permisos retribuidos. Comentario a la STS 145/2018 de 13 de febrero y las reacciones generadas en la audiencia nacional”, IUSLabor, no 1 (2019) 342-352.

${ }^{60}$ SSTS de 12 de mayo de 2009, rec. 4/2008, f. j. 4 o y de 13 de febrero de 2018, rec. 266/2016, f. j. 2o . Así, por ejemplo, el supuesto analizado en la sentencia de 2009 es muy acotado: el tribunal examina el dies a quo de un premiso por matrimonio de carácter convencional, aunque idéntico al previsto en el ET, que coincide con días libres, no planteándose qué sucede cuando se trata de otro permiso y cuando los días de no trabajo son de otra índole (por ejemplo, descanso semanal).
} 
laborable, se privaría de uno o más días de permiso a la persona trabajadora, lo cual es contrario al espíritu del art. $37.3 \mathrm{ET}^{61}$.

El segundo aspecto que aclara el Tribunal Supremo es que, al igual que sucede con el resto de los elementos presentes en el artículo 37.3 ET, la regulación legal constituye un mínimo de derecho necesario relativo, de modo que el convenio puede establecer un régimen distinto respecto del dies a quo, siempre que no resulte menos favorable que el legal. En realidad, tampoco se trata de una posición jurisprudencial nueva, pues, como ya se ha visto en diversas ocasiones, el Tribunal Supremo ha convalidado cláusulas convencionales que flexibilizaban el principio de razonable inmediación entre el hecho causante y el disfrute del permiso ${ }^{62}$. Lo único que hace ahora el Tribunal es recoger esa doctrina y aplicarla de manera más explícita a la determinación del dies a quo.

El mínimo de derecho necesario que establece el artículo 37.3 ET respecto del dies a quo cuando el hecho causante sucede en día no laborable, teniendo la relación laboral plena eficacia, es que el cómputo no se inicia hasta el primer día laborable, pues solo de este modo se logra preservar la duración legal del permiso. En uno de sus recientes pronunciamientos el Supremo convalida una cláusula convencional de la que se desprende que los días de permiso por accidente o enfermedad grave, hospitalización o intervención quirúrgica de parientes comenzarán a computarse desde el momento en que se produzca el hecho causante, aunque coincida con un día no laborable. La razón por la cual el Tribunal entiende que en este caso no es obligado situar el dies a quo en el siguiente día laborable radica en que la duración convencional de tales permisos era superior a la legal, de modo que el inicio del permiso en día no laborable no implicaba una merma en los derechos establecidos en el Estatuto de los Trabajadores, pues no rebajaba en la práctica la duración del permiso por debajo de la legal ${ }^{63}$.

En definitiva, si la norma convencional regula la duración de los permisos de forma más favorable que el ET, también podrá fijar el dies a quo en días no laborables, siempre que el resultado -esto es, los días de permiso disfrutados- no sea inferior al garantizado por el $\mathrm{ET}^{64}$.

Del mismo modo, puesto que la doctrina del Supremo sobre el dies a quo se circunscribe a los permisos previstos legalmente, cuando el convenio colectivo establezca permisos diferentes a los del artículo 37.3 ET, podrá establecer con total libertad su dies a quo, sin quedar vinculado por esta jurisprudencia ${ }^{65}$.

\subsection{B. El cómputo de los días de permiso una vez que ya se ha iniciado su disfrute}

El artículo 37.3 ET atribuye una duración concreta a cada uno de los permisos retribuidos que enumera y, como se acaba de ver, esta duración constituye un mínimo de Derecho necesario susceptible de mejora por la autonomía colectiva. Sin embargo, del precepto legal no se deduce con claridad

\footnotetext{
${ }^{61}$ Todos estos argumentos se encuentran ya presentes en la STS de 13 de febrero de 2018, rec. 266/2016, f. j. $2^{\circ}$. Aunque en esta sentencia el Tribunal Supremo interpreta los permisos de matrimonio, nacimiento de hijo, enfermedad, fallecimiento u hospitalización de familiar de un convenio colectivo, estos son idénticos a los del art. 37.3 ET, al que también se refiere. Por lo tanto, la doctrina vertida también sirve para interpretar el alcance del texto legal en esta materia. Recientemente reproducen y amplían esta doctrina las SSTS de 11 de marzo de 2020, rec. 192/2018, f. j. $3^{\circ}$ y $4^{\circ}$ y de 17 de marzo de 2020, rec. 193/2018, que de nuevo aborda la interpretación de una cláusula convencional, pero el Tribunal advierte de que "la redacción del convenio no difiere en esencia de lo dispuesto en el artículo 37.3 ET", de modo que se aplica la doctrina general sobre el dies a quo de los permisos retribuidos. Sobre estos últimos pronunciamientos, véase LAHERA FORTEZA, J., "Ejercicio y cómputo de los permisos retribuidos. Comentario a las Sentencias del Tribunal Supremo 229/2020 y 257/2020, de 11 y 17 de marzo", Revista de Trabajo y Seguridad Social. CEF, no 448 (2020) 169174 y RIVAS VALLEJO, P., "El cómputo del dies a quo en los permisos retribuidos en la jurisprudencia de la Sala cuarta del Tribunal Supremo", Revista de Jurisprudencia Laboral, no 6 (2020).

${ }^{62}$ Véanse las ya citadas SSTS de 17 de enero de 2008, rec. 24/2007 y de 29 de marzo de 2017, rec. 61/2016.

${ }^{63}$ STS de 11 de marzo de 2020, rec. 188/2018, f. j. 9o.4 y 5.

${ }^{64}$ Ibid., f. j. $9^{\circ} .4$.

${ }^{65}$ Idem.
} 
cuál es el mínimo imperativo, pues la norma no indica si se refiere a días laborables o días naturales, salvo en el permiso por matrimonio.

En efecto, el permiso de matrimonio es el único que especifica que los días establecidos son naturales. Con independencia de cómo se determine el dies a quo, lo que no ofrece duda es que, tratándose de días naturales, los días no laborables comprendidos dentro de los quince días de permiso quedan englobados en su cómputo. Según ha señalado recientemente el Tribunal Supremo, el hecho de que el artículo 37.3.a) ET se refiera a días naturales "solo significa que en el cómputo de tales quince días, una vez iniciado su devengo, no pueden excluirse los que no sean laborables para el trabajador" ${ }^{66}$. Obviamente, todo ello, salvo mejora del convenio colectivo.

Pero la cuestión no está tan clara respecto de los otros permisos del artículo 37.3 ET, en los que el sustantivo "días" no va acompañado de ningún adjetivo, suscitando la duda de si han de computarse solo los días laborables, o bien si, una vez iniciado el disfrute del permiso, este se extiende también a los días no laborables que queden comprendidos dentro de su duración legal, de la misma manera que sucede con el permiso por matrimonio. Se trata de un tema relevante, pues del modo de cómputo depende la duración efectiva del permiso que debe ser respetada en todo caso por la negociación colectiva.

Hasta marzo de 2020 el Tribunal Supremo no había tenido ocasión de manifestarse sobre este extremo. La única referencia al respecto se contenía en la sentencia de 13 de febrero de 2018, en la que el Tribunal, tras razonar que el dies a quo de todos los permisos debe situarse en el primer día laborable, pues en día festivo no hace falta, puntualizaba que esta es una "cuestión distinta a la del cómputo de los días del permiso iniciado", dado así a entender que en ese cómputo ulterior podrían incluirse días no laborables ${ }^{67}$.

Sin embargo, una de las sentencias dictadas el 11 de marzo de 2020 despeja esta cuestión, y además lo hace de forma novedosa y opuesta al criterio tradicional, siguiendo una línea conexa con el razonamiento mantenido por el Tribunal para la determinación del dies a quo ${ }^{68}$. En esta sentencia el Tribunal debe decidir cómo ha de llevarse a cabo el cómputo de diversos permisos previstos en un convenio colectivo, algunos de ellos idénticos a los del art. 37.3 ET, tanto en su causa como en su duración. El convenio, al igual que el Estatuto de los Trabajadores, no especificaba si los días de permiso eran naturales o laborables. Pues bien, el Tribunal Supremo reitera que "el permiso sólo tiene sentido si se proyecta sobre un período de tiempo en el que existe obligación de trabajar, pues -de lo contrario- carecería de sentido que su principal efecto fuese "ausentarse del trabajo"; en consecuencia, lo normal es que los permisos se refieran a días laborables, salvo previsión normativa en contrario" ${ }^{69}$.

De ahí se deduce, en primer lugar, que la duración asignada por el artículo 37.3 ET a todos los permisos, salvo al de matrimonio, debe entenderse fijada en días laborables. Por tanto, si en el curso del disfrute del permiso quedan comprendidos uno o más días no laborables, el cómputo se suspende y se reanuda en el siguiente día laborable ${ }^{70}$. Esta solución no debería ser aplicable a los periodos no laborables más amplios, como las vacaciones o las suspensiones del contrato de trabajo,

${ }^{66}$ STS de 17 de marzo de 2020, rec. 193/2018, f. j. $4^{\circ}$.

${ }^{67}$ STS de 13 de febrero de 2018 , rec. 266/2016, f. j. $2^{\circ}$.

${ }^{68}$ STS de 11 de marzo de 2020, rec. 192/2018.

${ }^{69}$ STS de 11 de marzo de 2020, rec. 192/2018, f. j. $4^{\text {o }}$.

${ }^{70}$ De este modo el Tribunal Supremo se aparta de la vieja doctrina del Tribunal Central de Trabajo, que se ha venido aplicando en defecto de jurisprudencia más moderna al respecto. Véase SÁNCHEZ TRIGUEROS, C., "¿Puede posponerse el disfrute de los permisos por razones familiares al momento en que se debería trabajar? Comentario a la Sentencia del Tribunal Supremo 145/2018, de 13 de febrero", cit., 136, 137. Probablemente por ello algunos autores toman con prudencia las afirmaciones del Tribunal Supremo a este respecto, entendiendo que la cuestión no puede darse por zanjada y esperando que pueda ser aclarada en futuras sentencias (LAHERA FORTEZA, J., "Ejercicio y cómputo de los permisos retribuidos. Comentario a las Sentencias del Tribunal Supremo 229/2020 y 257/2020, de 11 y 17 de marzo", cit., 172-174). 
pues en tales casos quebraría el principio de razonable inmediación, aunque el convenio colectivo podría optar por una solución más favorable para las personas trabajadoras.

En segundo lugar, cuando el convenio colectivo regule expresamente los permisos retribuidos, si a la hora de establecer la duración de los permisos no dice nada, el cómputo de los días de permiso se hará teniendo en cuenta días laborables - que es precisamente lo que sucedía en el caso analizado por la sentencia-. Ahora bien, la negociación colectiva puede evitar este efecto indicando expresamente que se trata de días naturales, con la única condición de que el resultado práctico no sea peor al que le correspondería a la persona trabajadora de ser de aplicación el régimen legal del artículo 37.3 ET. Es decir, la opción del convenio colectivo por el cómputo en días naturales no puede dar lugar a permisos más cortos que los que corresponderían si este se hiciese en días laborables.

4.3.C. Algunas dificultades en torno a la identificación de los días laborables y la jornada de trabajo afectados por los permisos

Por último, hay que referirse a una última cuestión que se desprende de la jurisprudencia anterior y que se refiere al concepto de día laborable. Si bien el concepto de día natural no ofrece dudas, pues comprende todos los días del año, el concepto de día laborable en el marco de la relación de trabajo puede tener dos acepciones: puede tratarse de los días seńalados como de actividad productiva en términos globales en la empresa o centro de trabajo, con independencia de que no toda la plantilla acuda a trabajar simultáneamente; o bien puede tratarse de los días en que efectivamente ha de prestar servicios la persona trabajadora titular del derecho al permiso retribuido.

Si los permisos han de computarse en días laborables, siempre que una norma legal o convencional no opte por el cómputo en días naturales, es preciso determinar si aquellos son los días laborables para la empresa o para la persona trabajadora, pues las dos acepciones podrían no coincidir. $\mathrm{Al}$ margen de que alguna sentencia dictada en el pasado optase por la interpretación de que se trata de los días laborables en la empresa o centro de trabajo ${ }^{71}$, la solución que se desprende de la actual doctrina del Tribunal Supremo en esta materia es que hay que tener en cuenta los días laborables para la persona trabajadora, pues este es el enfoque adopta el Tribunal en las sentencias de marzo de 2020 cuando indica que el permiso solo tiene sentido si se proyecta sobre un período de tiempo en el que existe obligación de trabajar. En consecuencia, si una persona tiene derecho a un permiso de cinco días laborables, por ejemplo, y solo presta servicios tres días a la semana, seguirá haciendo uso del mismo la semana siguiente, aunque la semana laborable en la empresa sea más amplia, siempre que persista la situación de necesidad que lo ha motivado.

La opción del Tribunal Supremo por centrarse en la jornada real de la persona trabajadora, a efectos de determinar sus días de permiso se deduce también de la postura adoptada respecto de los trabajadores sujetos a jornadas irregulares. Sin embargo, en estos casos el Tribunal admite el establecimiento por parte del convenio colectivo de reglas correctoras cuando la distribución irregular no solo alcanza a los días de trabajo mensuales, sino también a las horas de trabajo diarias.

En efecto, a lo largo de 2020 el Tribunal Supremo ha tenido ocasión de analizar la problemática que presenta el cómputo de horas asignadas a los días de permiso en el sector de empresas de seguridad, donde se ha producido históricamente una fuerte conflictividad en torno a esta cuestión derivada de las particularidades que presenta la determinación de la jornada diaria ${ }^{72}$. En efecto, es práctica habitual en estas empresas la fijación de los horarios de trabajo en función de las necesida-

${ }^{71}$ STS de 12 de julio de 1993, rec. 1000/1992.

${ }^{72}$ STS de 12 de marzo de 2020, rec. 175/2018. 
des de los clientes, lo que en muchas ocasiones obliga a elaborar cuadrantes horarios con carácter mensual. Por esta razón, el convenio colectivo sectorial fija la jornada en términos anuales y mensuales, pero no diarios. Puesto que las horas de trabajo diarias también son variables, el convenio sectorial ha optado por aplicar un sistema proporcional, que atribuye a cada día de permiso un número de horas calculadas en función de la jornada mensual, es decir, una jornada promedio. A ello se ańaden ciertas garantías para evitar, primero, que el disfrute del permiso implique un déficit de jornada, si las horas de la jornada real no alcanzan la jornada diaria promedio, y segundo, que la retribución sea insuficiente, si la jornada real supera a la jornada diaria promedio.

Pues bien, el Tribunal Supremo ha apoyado la validez de este sistema convencional, entendiendo que se trata de una "solución lícita y equilibrada" que no se opone al tenor literal del artículo 37.3 ET, pues este solo se refiere a días o días naturales, sin que en ningún caso "se indique el tiempo que ha de ser computable como jornada en tales días". Por tanto, cabe deducir que si el convenio colectivo no dice nada, el permiso deberá abarcar la jornada real del trabajador en los días afectados. Ahora bien, "cuando la jornada programada a desarrollar por los empleados es totalmente heterogénea y diversa”, como sucede en el sector de la vigilancia de seguridad, es posible que el convenio establezca un sistema ponderado para calcular las horas asignadas al disfrute del permiso ${ }^{73}$.

El supuesto analizado por el Tribunal Supremo es interesante, pues las jornadas irregulares que comportan apreciables diferencias en la duración de la jornada diaria cada vez son más habituales, y la sentencia convalida una solución convencional que pretende equilibrar los intereses y derechos de empresas y personas trabajadoras. En todo caso, hay que tener en cuenta que el artículo 37.3 ET establece un mínimo de derecho necesario y que, aunque no se refiere al número de horas de trabajo que integran cada día de permiso, la aplicación de promedios por parte de la negociación colectiva no puede comportar para la persona trabajadora el adeudo de horas de trabajo, ni una merma en su retribución.

\section{Reflexión final}

Pese a tratarse de una institución con una amplia tradición en el ordenamiento laboral, el uso de los permisos retribuidos constituye una fuente de notable litigiosidad. Entre los factores que contribuyen a ello destacan las complejidades en la articulación entre la ley y el convenio colectivo, las particularidades de la jornada de trabajo de las personas trabajadoras y la intensa casuística que se da en la práctica en torno al disfrute de los permisos y su combinación con los tiempos de actividad e inactividad.

Las recientes sentencias del Tribunal Supremo han contribuido a modernizar esta institución incluyendo la perspectiva de género en el análisis de la retribución correspondiente a los permisos, pero a su vez mantienen un enfoque fuertemente tuitivo al determinar la necesaria coincidencia de los días de permiso reconocidos en el artículo 37.3 ET con días laborables de la persona trabajadora. No deja de llamar la atención esta sólida defensa de los intereses de las personas trabajadoras, que no repara en el coste económico que los permisos comportan para la empresa, en un contexto en el que muchas instituciones laborales han perdido en buena parte su originario carácter tuitivo y pretenden equilibrar los intereses de trabajadores y empresarios o bien, de manera más directa, favorecer la competitividad empresarial. Estas tendencias no han logrado penetrar en la institución de los permisos retribuidos, pues la jurisprudencia del Tribunal Supremo blinda la concepción de esta institución como un auténtico derecho de las personas trabajadoras en caso de conflicto entre sus obligaciones laborales y su vida personal y familiar, cuyo disfrute ha de ser plenamente garantizado.

${ }^{73}$ STS de 12 de marzo de 2020, rec. 175/2018, f. j. $1^{\text {o }}, 2^{\text {o }}$ y $3^{\text {o. }}$. 
Pese a todo, las recientes sentencias del Supremo no agotan las cuestiones que pueden plantearse en torno a los permisos retribuidos, por lo que cabe esperar que se sigan produciendo pronunciamientos al respecto. La creciente flexibilidad de las jornadas de trabajo, la irrupción del trabajo a distancia y las intensas necesidades de conciliación desencadenadas por la actual situación de pandemia conforman un escenario muy propicio para una revisión de esta institución que garantice su ajuste al trabajo del siglo XXI sin perder la mirada protectora inherente al Derecho del Trabajo. 